\title{
Gingival Leukemic Infiltration in Chronic Lymphocytic Leukemia
} Kronik Lenfositik Lösemide Gingival Lösemik Infiltrasyon

(D) Karima Kacem 1,2, (D) Sami Zriba33, (D) Myriam Saadi2, (D) Raoudha Doghri4

${ }^{1}$ Tunis El Manar University Faculty of Medicine, Department of Hematology, Tunis, Tunisia

${ }^{2}$ Aziza Othmana Hospital, Clinic of Clinical Hematology, Tunis, Tunisia

3 Military Hospital, Clinic of Clinical Hematology, Montfleury, Tunisia

4 Institute Salah Azaïz, Department of Pathology, Tunis, Tunisia

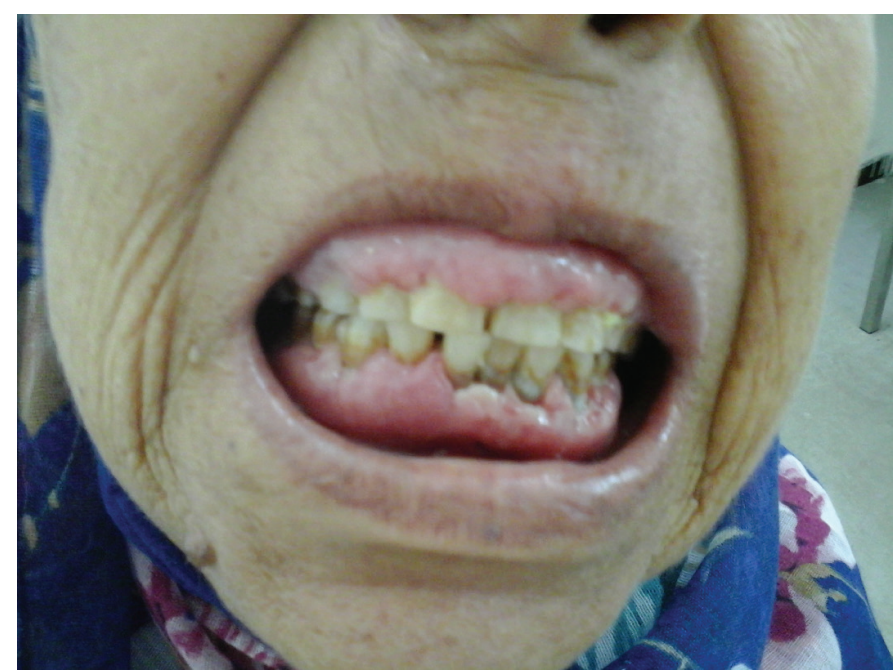

Figure 1. Physical examination revealed gingival enlargement with swollen margins and glossy texture.
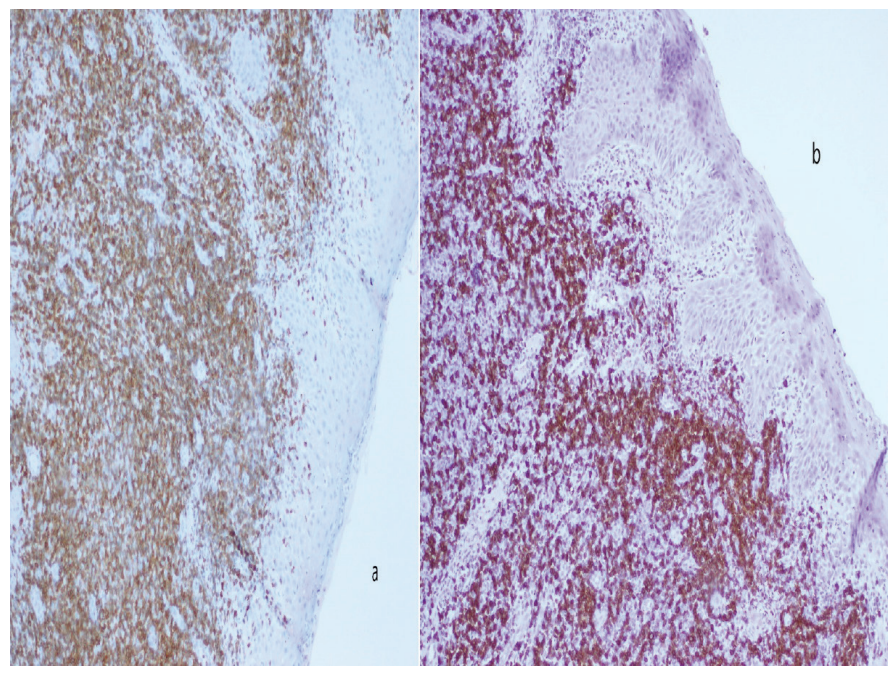

Figure 2. A biopsy of the gingiva showed infiltration by small lymphocytes expressing CD5 and CD20 positivity.
A 66-year-old female patient was referred for asymptomatic peripheral blood lymphocytosis. The blood smear showed 77\% mature lymphocytes. Flow cytometry confirmed the clonality of the circulating B lymphocytes with positivity for CD19, CD5, and CD23. The patient was diagnosed with chronic lymphocytic leukemia (CLL), stage $A$, and a decision was made to watch and wait. Six years later, she was referred again for multiple adenopathy with splenomegaly. She reported a toothache that was worse upon biting, causing food restriction. Physical examination revealed multiple cervical lymphadenopathy, splenomegaly, and gingival enlargement with swollen margins and glossy texture (Figure 1). There were no exudates, necrosis, ulcerations, or active bleeding. Laboratory evaluation revealed a white blood cell count of $71,000 / \mathrm{mm}^{3}$, hemoglobin of $7.2 \mathrm{~g} / \mathrm{dL}_{\text {, and platelet count }}$ of $294,000 / \mathrm{mm}^{3}$. A biopsy of the gingiva showed infiltration by small lymphocytes expressing CD5 and CD20 positivity (Figures $2 \mathrm{a}$ and $2 \mathrm{~b}$ ). This typical pattern of CLL infiltration excluded a diagnosis of prolymphocytic leukemia or a transformation into aggressive lymphoma. The patient was treated with rituximab and chlorambucil for CLL, stage C. Gingival enlargement was less painful after one cycle, with reduction of the swelling. The patient was lost after the third cycle. Gingival hyperplasia due to leukemic infiltration is commonly observed in acute leukemia but is rare in CLL and represents an extranodal site. To our

๑Copyright 2019 by Turkish Society of Hematology

Turkish Journal of Hematology, Published by Galenos Publishing House

口. Address for Correspondence/Yazışma Adresi: Karima KACEM, M.D., Tunis El Manar University Faculty of Medicine, Department of Hematology, Tunis, Tunisia

Phone : 21671563709

E-mail : karimakacem9@gmail.com ORCID: orcid.org/0000-0002-0067-5636 
knowledge, only two prior cases were reported in the literature $[1,2]$.

Keywords: Chronic lymphocytic leukemia, CD19, Leukemia Anahtar Sözcükler: Kronik lenfositik lösemi, CD19, Lösemi

Conflict of Interest: The authors of this paper have no conflicts of interest, including specific financial interests, relationships, and/or affiliations relevant to the subject matter or materials included.

\section{References}

1. Wentz FM, Anday G, Orban B. Histopathologic changes in the gingiva in leukemia. J Periodontol 1949;20:119-128.

2. Present CA, Safdar SH, Cherrick H. Gingival leukemic infiltration in chronic lymphocytic leukemia. Oral Surg Oral Med Oral Pathol 1973;36:672-674. 